\title{
Sorgulamaya dayalı öğretimin "lamba parlaklığı" kavramının ortaokul 5. sınıf öğrencilerinin başarısına etkisi
}

\author{
Ayberk BOSTAN SARIOĞLAN ${ }^{1 *}$, Bengisu ABACI ${ }^{2}$ \\ ${ }^{1}$ Balıkesir Üniversitesi, Necatibey Eğitim Fakültesi, Matematik ve Fen Bilimleri Eğitimi Bölümü, Balıkesir \\ ${ }^{2}$ Balıkesir Üniversitesi, Fen Bilimleri Enstitüsü, Matematik ve Fen Bilimleri Eğitimi Bölümü, Balıkesir \\ Geliş Tarihi (Recived Date): 05.09.2017 \\ Kabul Tarihi (Accepted Date): 30.11 .2017
}

Özet

Son yıllarda eğitimde sorgulamaya dayalı öğrenme yaklaşımının öğrencilerin başarısına, kavramsal anlamalarına ve tutum etkisi araştırılmış ve hala araştırılmaya devam etmektedir. Bu çalışmada sorgulamaya dayalı öğrenmenin beşinci sınıf yaşamımızdaki elektrik ünitesinin lamba parlaklı̆̆ ile ilgili kazanımı üzerine etkisinin araştırılması amaçlanmaktadır. Çalışma grubu olarak bir devlet ortaokulundaki beşinci sınıfta öğrenim görmekte olan 30 ögrrenci belirlenmiştir. Araştırma kapsamında veri toplama aracı olarak sekiz sorudan oluşan açıklamall-çoktan seçmeli kavramsal anlama testi öğretim öncesi ve öğretim sonrası öğrencilere uygulanmıştır. Kavramsal anlama testine öğrencilerin verdikleri cevaplardan elde edilen sonuçlara göre öğrencilerde öğretim sonrasında öğretim öncesine kıyasla bilimsel cevabı verme oranında artış olduğu belirlenmiştir. Ayrıca lamba parlaklığı ile ilgili öğrencilerin kavram yanılgıları ile karşılaşılmış ve öğretim sonrası öğrencilerde karşılaşılan bu kavram yanılgılarının görülme sıklı̆̆ azalmıştır.

Anahtar kelimeler: Sorgulamaya dayalı öğrenme, lamba parlaklı̆̆l, kavramsal anlama.

\section{The effect of inquiry based learning approach about "light bright" concept on 5th grade middle school students}

\begin{abstract}
In recent years, the effect of the inquiry-based learning approach in education on the success of students, conceptual understanding and attitude have been researched and is still being investigated. In this study, it is aimed to investigate the effect of inquiry based learning on 5th grade students about electric unit on lamp brightness gain. The study group identified 30 students who were studying in the fifth grade in a state middle school. Explanatory-multiple-choice concept assessment test consisting of eight questions as data collection tool was applied before and after instruction at study group. According to the results obtained from the answers given by the students to the conceptual understanding test, it was determined that the students giving scientific answer rate increased as a result of the inquiry based learning. In addition, students' misconceptions regarding the brightness of the lamp have been encountered and the frequency of these misconceptions encountered after instruction has decreased.
\end{abstract}

Keywords: Inquiry based learning, light bright, conceptual understanding.

\footnotetext{
*Ayberk BOSTAN SARIOĞLAN, abostan@balikesir.edu.tr, http://orcid.org/0000-0002-2320-9427

Bengisu ABACI, bengisuabaci@gmail.com, http://orcid.org/0000-0002-4381-0586
} 


\section{Giriş}

Öğrenme çabası insanları doğuştan itibaren araştırmaya ve bulmaya yönlendirir. $\mathrm{Bu}$ çaba sayesinde insanoğlu ömrünün ilk gününden itibaren araştırma ve sorgulama yapar. Günümüzde ise hızla ilerleyen ve araştırmalarının arttığı sorgulamaya dayalı öğrenme tekniği ile geleneksel öğretim anlayışından çıkılıp öğrenciyi aktif kılarak araştırmalarına, soru sormalarına ve cevap aramalarına yönlendiren ders öğretimi yapılmaya başlanmıştır. Bu öğretimin çocuklar tarafından daha çok benimsenip gerçek hayatla ilişkilendirildiği gözlemlenmiştir [1] .

Öğrencilerin derse yönelimlerini ve ders karşı tutumlarını arttırmak için; öğrencilere araştırmalar verip, hipotez oluşturmaları istenilip, bilgilere kendilerinin ulaşmasını sağlama ve sonuçlarına yorumlar getirmesine firsat tanımalıyı [2]. Fen derslerinde sorgulamaya dayalı öğrenme ile öğrencilerin öğrenirken kendileri için önemli olan kararı verebilmeleri, istenilen konularda araştırmalar yapmaları ve kendilerine özgü öğrenme teknikleri oluşturmaları beklenir. $\mathrm{Bu}$ süreçte öğrenciler önceden yaşadıkları olaylarla edindikleri kazanımları birleştirerek yol alırlar. Eğer fen eğitiminde öğretmenlerimiz öğrencilerin ilgisini derse kazandırıp uygun öğrenme koşulları hazırlarlarsa öğrenciler derslerde aktif katılım sağlayabilirler [3]. Öğrencilerin aktif olması demek yaşadıkları dünyayı daha kolay anlayabilmeleri ve yeni bilgileri sayesinde kendilerini geliştirme becerileri kazanmaları sağlamak demektir. $\mathrm{Bu}$ beceriler sayesinde öğrenciler günlük hayatlarını da kolaylaştırabilirler.

Öğrencilerin merak duygularını giderebilmek için uygun ortam ve koşullar hazırlanarak öğrenmelerinin ve ilgilerinin artması sağlanabilir. Öğrenci bu öğrenme olanağı sayesinde öğrenmeye teşvik ettirilmiş olur. $\mathrm{Bu}$ durum öğrencilerde araştırma sorgulama ve öğrenme yönelimi sağlar.

\subsection{Sorgulamaya dayalı öğrenme}

Sorgulamaya dayalı öğrenme, sorular sorarak, araştırarak ve bilgileri analiz ederek öğrenme ve verileri yararlı bilgilere dönüştürme süreci olarak tanımlanmaktadır [4]. Öğrenciler sorgulamayı etrafında olup bitenleri anlamak bilinmezi bulmak ve doğaya anlam vermek için gerçekleştirir.

Sorgulamaya dayalı öğretimde genellikle 5E öğrenme modeli kullanılarak gerçekleştirilir. Öğrencide ilgi çekilir, öğrenciye uygun ortam sağlayarak bilgileri gözlem yapmaları sağlanır, kavramları genellemeler ile açıklar ve kavramları yeni ortamlarda kullanması sağlanır. Bu öğrenme şekli sayesinde öğrencide istendik birçok değişiklik gerçekleşir. Bu model; giriş, keşfetme, açıklama, genişletme ve değerlendirme olarak beş aşamadan oluşmaktadır [5].

- Giriş: öğrencilerin dikkatini çekmek ve düşünmeye teşvik edilen ön bilgilerin ortaya çıkarıldığı aşama.

- Keşfetme: Öğrencilerin araştırarak gözlem yaparak verileri toparlayıp onları kullanarak hipotez oluşturmalarını sağlayarak kavramları keşfettikleri aşama.

- Açıllama: Öğrencilerin ulaştıkları bilgiyi açıklamalarına fırsat verildiği ve öğretmenin keşfettikleri kavramları genellediği aşama.

- Genişletme: öğrencilerin öğrenmiş olduğu kavramları yeni ortamlara uyarlayarak bilgileri kullandığı aşama.

- Değerlendirme: öğretmenin, öğrencilerin kavramları ne kadar öğrendiğini değerlendirdiği öğrencinin öz değerlendirme yaptığı aşama.

\section{2. Çalışmanın amacı}

$\mathrm{Bu}$ çalışmada; öğrencilerde sorgulamaya dayalı öğrenme tekniği kullanılarak öğrenciyi teşvik ederek öğrenmenin öğrenciler tarafından gerçekleştirilmesi sağlanmış ve bu öğrenme sonucunda tekniğin öğrencilerdeki fen bilgisi dersine karşı başarı etkisi araştırılmıştır.

\section{Yöntem}

\subsection{Araşturma modeli}

$\mathrm{Bu}$ çalışma, araştırma türlerinden zayıf deneysel desen açıklamalı çoktan seçmeli, ön-test son-test tek grup içeren nitel bir çalışmadır.

\section{2. Örneklem}

Araştırmanın örneklemini 2016-2017 eğitim-öğretim yılı bahar döneminde Manisa ilinin Akhisar ilçesinde bulunan toplam 30 beşinci sınıf öğrencileri oluşturmaktadır. Uygulama tek örneklem grubu seçilerek gerçekleştirilmiştir. (Erkek=13, Kız=17)

\subsection{Veri toplama aract}

Araştırmada veri toplama aracı olarak ortaokul beşinci sınıf fen bilimleri dersinin "Yaşamımızdaki Elektrik" ünitesi ile ilgili "Bir elektrik devresindeki lamba parlaklığını etkileyen değişkenlerin neler olduğunu tahmin eder ve tahminlerini test eder" kazanımı göz önüne alınarak hazırlanan Basit Elektrik Devreleri Başarı Testi deneysel işlem öncesinde ön test, deneysel işlem sonrasında son test olarak uygulanmıştır. Başarı testi [6] tarafından geliştirilmiştir. Testte 8 tane çoktan seçmeli açıklamalı soru kullanılmıştır. Sorularda lamba parlaklığını değiştiren etkenler sorularak öğrencilerde kazanımlara uygun öğrenim gerçekleşip gerçekleşmediğine bakılmıştır. Birinci soruda lamba parlaklığını etkileyen etkenler 
hakkında ifadeler verilip doğru olan ifadelerin bulunması istenmiştir. İkinci soruda ampul sayısının sabit pil sayısının artış gösterdiği durumda lamba parlaklığının durumu sorulmuştur. Üçüncü soruda seçeneklerdeki lamba parlaklığını arttıran etken sorulmuştur. Dördüncü soruda pil sayısı sabit ampul sayısının artması durumunda lamba parlaklığının durumu sorulmuştur. Beşinci soruda seçeneklerdeki hangi etkenin lamba parlaklığını değiştirmediği sorulmuştur. Altıncı soruda verilmiş olan örnek devrelerden hangi lambanın parlaklığı daha fazla olacağ1 sorulmuştur. Yedinci soruda hangi seçenekteki lambanın daha parlak yanacağ sorulmuştur. Sekizinci soruda örnek olarak verilen devrelerdeki lambaların parlaklıklarının karşılaştırılıp sıralanması sorulmuştur.

\subsection{Veri toplama süreci}

2016-2017 bahar döneminde yapılmış olan ders saatleri içerisinde uygulama öğretmeni tarafından yapılmıştır. Uygulama öğretmeninin bu konuda eğitimi olup tecrübesi vardır. Uygulama planı sorgulamaya dayalı öğrenme tekniğinin 5E modelince uyarlanmıştır. Ders öncesi ön test olarak başarı testi uygulanmış ve 5E'ye uyarlanmış olan sorgulamaya dayalı öğrenme planı uygulanmıștır. Öğrencilere planda deney tasarlanmış ve bu deneyin öğretimi 5E modeliyle gerçekleştirilmiştir. Uygulama sonrasında öğrencilere son test olarak başarı testi yeniden uygulanmıștır.

\subsection{Verilerin analizi}

Öğretim öncesi ve öğretim sonrası öğrencilere uygulanan başarı testinde yer alan soruların analizinde üç ana kategori ve bu kategorilerin altında yer alan alt kategorilerden oluşan bir rubrik kullanılmıştır. Doğru cevap kategorisinde, doğru cevap ve sorunun doğru açıklaması, doğru cevap ve kısmen doğru açıklama, doğru cevap ancak yanlış açıklama ve doğru cevap açıklama yok alt kategorileri yer almaktadır. Yanlış cevap kategorisinde sorunun cevabı yanlış açıklamanın doğru olduğu yanlış cevap tam doğru açıklama, yanlış cevap ve kısmen doğru açıklama, yanlış cevap ve yanlış açıklama ve yanlış cevap ve açıklama yok alt kategorileri yer almaktadır. Son cevap kategorisi de konu ile ilgili görüş belirtmeyen öğrencilerin yer aldığı cevap yok kategorisidir. Öğrencilerin öğretim öncesi ve sonrası verdikleri cevapların cevap kategorilerinde yer alma frekansları ve yüzdeleri hesaplanmıştır.

\section{Bulgular}

$\mathrm{Bu}$ bölümde araştırmanın verilerine dayalı olarak elde edilen bulgulara yer verilmektedir. Araştırmada ilk olarak kazanıma yönelik ön test ve son test sonuçları incelenmiş ve karşılaştırılmıştır.

1. I. Basit bir elektrik devresinde ampul sayısı sabitken pil sayısı artarsa ampullerin parlaklığı artar.

II. Basit bir elektrik devresinde ampul sayısı sabitken pil sayısını azalırsa ampullerin parlaklığı artar.

III. Basit bir elektrik devresinde pil sayısı sabitken ampul sayısını artarsa ampullerin parlaklığı artar.

IV. Basit bir elektrik devresinde pil sayısı sabitken ampul sayısını artarsa ampullerin parlaklığı azalır.

\section{Yukarıdaki cümlelerden hangisi ya da hangileri} doğrudur?
A. II ve III
B. I ve IV
C. I ve II
D. I ve III

\section{Verilen cevabın nedeni:}

Birinci sorunun analiz ve bulguları Tablo 1'de verilmiştir.

Tablo 1: Birinci soru analizinden elde edilen veriler

\begin{tabular}{|c|c|c|c|c|}
\hline \multirow[b]{3}{*}{ Doğru Cevap } & \multicolumn{2}{|c|}{ Ön Test } & \multicolumn{2}{|c|}{ Son Test } \\
\hline & f & $\%$ & f & $\%$ \\
\hline & 18 & 60 & 28 & 93.3 \\
\hline Doğru Cevap Tam Doğru Açıklama & 1 & 3.3 & 4 & 13.3 \\
\hline Doğru Cevap Kısmen Doğru Açıklama & 6 & 20 & 14 & 46.7 \\
\hline Doğru Cevap Yanlış Açıklama & 3 & 10 & 10 & 33.3 \\
\hline Doğru Cevap Açıklama Yok & 8 & 26.7 & - & 0 \\
\hline Yanlış cevap & 12 & 40 & 2 & 6.7 \\
\hline Yanlıș Cevap Tam Doğru Açıklama & - & 0 & - & 0 \\
\hline Yanlıș Cevap Kısmen Doğru Açıklama & - & 0 & 1 & 3.3 \\
\hline Yanlış Cevap Yanlış Açıklama & 8 & 26.7 & 1 & 3.3 \\
\hline Yanlıș Cevap Açıklama Yok & 4 & 13.3 & - & 0 \\
\hline Cevap Yok & - & 0 & & 0 \\
\hline
\end{tabular}

Başarı testi birinci sorusunda ön test doğru oranına $(\mathrm{f}=18)$ göre son testte $(\mathrm{f}=28)$ artış vardır. Öğrenciler lamba parlaklığını etkileyen etkenleri ön testte öğretim öncesi olduğu için tahminlerde bulunmuş ve tahminlerinde pil sayıs1 artar ifadesindeki etkeni doğru tahmin etmiş ancak lamba sayısı etkenini doğru tahmin edememiştir. $\mathrm{Bu}$ sebepten dolayı doğru frekansı düşük iken son testte öğrenim sonrası büyük bir artışla lamba parlaklığını etkileyen etkenleri doğru bilmişlerdir. 
Örnek olarak bazı açıklamalar aşağıda verilmiştir.

ÖF: 1-Ampul sayısı 1 iken pil sayısı 3'e çıkarılırsa parlaklık artar. Çünkü güç daha çok çoğalır. (Tam Doğru Cevap)

ÖR: 1'de pil sayısı fazla olduğu için fazla ışık verir. Diğerinde ise ampul sayısı artarsa 1 şı̆̆ da azalır. (Kısmen Doğru Cevap)

ÖN: Çünkü verilen bulgular doğrudur. (Yanlış Cevap)
2. Bir elektrik devresinde ampul sayısı sabit tutulup pil sayısı arttırıldığında ampulün parlaklığı için söylenenlerden hangisi doğrudur?
A. Artar
B. Azalır
C. Tamamen Söner
D. Değișmez

\section{Verilen cevabın nedeni:}

İkinci sorunun analizi ve bulguları Tablo 2'de verilmiştir.

Tablo 2: İkinci soru analizinden elde edilen veriler

\begin{tabular}{lcccc}
\hline & \multicolumn{2}{c}{ Ön Test } & \multicolumn{2}{c}{ Son Test } \\
\hline & $\mathrm{f}$ & $\%$ & $\mathrm{f}$ & $\%$ \\
\cline { 2 - 5 } Doğru Cevap & 26 & 86.7 & 29 & 96.7 \\
\hline Doğru Cevap Tam Doğru Açıklama & 7 & 23.3 & 14 & 46.7 \\
Doğru Cevap Kısmen Doğru Açıklama & 6 & 20 & 13 & 43.3 \\
Doğru Cevap Yanlış Açıklama & 5 & 16.7 & 2 & 6.7 \\
Doğru Cevap Açılama Yok & 8 & 26.7 & - & 0 \\
\hline Yanlıș cevap & 4 & 13.3 & - & 3.3 \\
\hline Yanlış Cevap Tam Doğru Açıklama & - & 0 & - & 0 \\
Yanlıș Cevap Kısmen Doğru Açıklama & - & 0 & 1 & 3.3 \\
Yanlış Cevap Yanlış Açıklama & 4 & 13.3 & - & 0 \\
Yanlış Cevap Açıklama Yok & - & 0 & - & 0
\end{tabular}

Doğru cevapta artış söz konusudur. Ön test $(\mathrm{f}=26)$ son test $(\mathrm{f}=29)$ ve yüzdelik dilimde $\% 10$ artış söz konusudur (ön test $\mathrm{f}=86.7$, son test $\mathrm{f}=96.7$ ). Öğrenciler ikinci soruda ampul sayısı sabit tutulup pil sayısı artışının lamba parlaklığı etkisinin yaşanmışlıklarından dolayı birçoğu doğru tahmin etmiş ve ön test son test arasında tabi ki artış gözlemlenmiştir ancak bu artış oranı çok fazla değildir. Sonuç olarak sınıfın \%96.7 si pil sayısının lamba parlaklığına etkisini doğru olarak cevaplamıştır.

Örnek olarak bazı açıklamalar aşağıda verilmiştir.

ÖM: Çünkü pillerden ampule daha fazla enerji gidecek bu yüzden artar. (Tam Doğru Cevap)

ÖM1: Enerji yetmez. (Yanlış Cevap)

3. Basit bir elektrik devresine aşağıdakilerin hangisi eklenirse ampulün parlaklığı artar?
A. Pil
B. Ampul
C. Anahtar
D. Bağlantı Kablosu

\section{Verilen cevabın nedeni:}

Üçüncü sorunun analizi ve bulguları Tablo 3'te verilmiştir.

Tablo 3: Üçüncü soru analizinden elde edilen veriler

\begin{tabular}{|c|c|c|c|c|}
\hline \multirow[b]{3}{*}{ Doğru Cevap } & \multicolumn{2}{|c|}{ Ön Test } & \multicolumn{2}{|c|}{ Son Test } \\
\hline & $\mathrm{f}$ & $\%$ & $\mathrm{f}$ & $\%$ \\
\hline & 26 & 86.7 & 30 & 100 \\
\hline Doğru Cevap Tam Doğru Açıklama & 5 & 16.7 & 13 & 43.3 \\
\hline Doğru Cevap Kısmen Doğru Açıklama & 14 & 46.7 & 15 & 50 \\
\hline Doğru Cevap Yanlış Açıklama & 3 & 10 & 2 & 6.7 \\
\hline Doğru Cevap Açıklama Yok & 4 & 13.3 & - & 0 \\
\hline Yanlış cevap & 4 & 13.3 & - & 0 \\
\hline Yanlış Cevap Tam Doğru Açıklama & - & 0 & - & 0 \\
\hline Yanlış Cevap Kısmen Doğru Açıklama & - & 0 & - & 0 \\
\hline Yanlış Cevap Yanlış Açıklama & 4 & 13.3 & - & 0 \\
\hline Yanlış Cevap Açıklama Yok & - & 0 & - & 0 \\
\hline Cevap Yok & - & 0 & - & 0 \\
\hline
\end{tabular}

Ön testte yapılan 4 yanlış cevap doğru cevap kısmına geçmiş olup hiç yanlış cevap verilmemiştir yani tabloya baktığımızda artış söz konusudur. İkinci sorudaki gibi pil artışı lamba parlaklığına olumlu etki gösterip artışına neden olacağını çoğunluk ön testte bilerek doğru cevap vermiştir.
Son testte bu doğru cevap sayısı \%100 olarak bulunmuştur.

Örnek olarak bazı açıklamalar aşağıda verilmiştir.

ÖE: Çünkü ampul iki alınırsa 1şık fazla çıkar. (Ön Test) 
ÖE: Çünkü pil fazla olursa enerji yani elektrik fazla olur. (Son Test)

4. "Bir elektrik devresinde pil sayıs1 sabitken ampul sayısının arttırılması ampulün parlaklığını

Yukarında boş bırakılan yere aşağıdakilerden hangisi getirilmelidir?
A. Azaltır
C. Değiştirmez
B. Arttırır
D. Önce arttırır sonra azaltır

\section{Verilen cevabın nedeni:}

Dördüncü sorunun analizi ve bulguları Tablo 4'te verilmiştir.

Tablo 4: Dördüncü soru analizinden elde edilen veriler

\begin{tabular}{|c|c|c|c|c|}
\hline \multirow[b]{3}{*}{ Doğru Cevap } & \multicolumn{2}{|c|}{ Ön Test } & \multicolumn{2}{|c|}{ Son Test } \\
\hline & $\mathrm{f}$ & $\%$ & $\mathrm{f}$ & $\%$ \\
\hline & 14 & 46.7 & 27 & 90 \\
\hline Doğru Cevap Tam Doğru Açıklama & 2 & 6.7 & 3 & 10 \\
\hline Doğru Cevap Kısmen Doğru Açıklama & 7 & 23.3 & 19 & 63.3 \\
\hline Doğru Cevap Yanlış Açıklama & 2 & 6.7 & 5 & 16.7 \\
\hline Doğru Cevap Açıklama Yok & 3 & 10 & - & 0 \\
\hline Yanlış cevap & 16 & 53.3 & 2 & 6.7 \\
\hline Yanlış Cevap Tam Doğru Açıklama & - & 0 & - & 0 \\
\hline Yanlış Cevap Kısmen Doğru Açıklama & - & 0 & - & 0 \\
\hline Yanlış Cevap Yanlış Açıklama & 9 & 30 & 2 & 6.7 \\
\hline Yanlış Cevap Açıklama Yok & 7 & 23.3 & - & 0 \\
\hline Cevap Yok & - & 0 & 1 & 3.3 \\
\hline
\end{tabular}

Tabloya bakıldığında öğrenciler ön testte açıklama yapmakta zorlanırken son testte bütün sorular için açıklama yapılmıştır. Bu soruda öğrenci lamba sayısındaki artışın parlaklığı olumlu etkileyeceğini düşünmüştür. Ne kadar çok lamba o kadar parlaklık demektir ifadesi yer almış ve ön testte çoğunluk soruya yanlış cevap vermiştir. Son testte öğrenim sonrası öğrencilerin çoğunluğu artık lamba sayısının artışının lamba parlaklığını azalttığını öğrenerek soruya doğru cevaplar vermişlerdir.

Örnek olarak bazı açıklamalar aşağıda verilmiştir.

ÖK: Ön testte açıklaması yoktur.

ÖK: Çünkü daha fazla enerji alır. (Son test)
5. Aşağıdakilerden hangisi basit bir elektrik devresindeki lambanın parlaklığını değiştirmez?

A. Pil sayısını artırma

B. Pil sayısını azaltma

C. Lambanın yerini değiştirme

D. Lamba sayısını artırma

\section{Verilen cevabın nedeni:}

Beşinci sorunun analizi ve bulguları Tablo 5'te verilmiştir.

Tablo 5: Beşinci soru analizinden elde edilen veriler

\begin{tabular}{lcccc}
\hline & & Ön Test & \multicolumn{2}{c}{ Son Test } \\
\hline & $\mathrm{f}$ & $\%$ & $\mathrm{f}$ & $\%$ \\
\cline { 2 - 5 } Doğru Cevap & 27 & 90 & 29 & 96.7 \\
\hline Doğru Cevap Tam Doğru Açıklama & 4 & 13.3 & 6 & 20 \\
Doğru Cevap Kısmen Doğru Açıklama & 13 & 43.3 & 21 & 70 \\
Doğru Cevap Yanlış Açıklama & 3 & 10 & 1 & 3.3 \\
Doğru Cevap Açıklama Yok & 7 & 23.3 & 1 & 3.3 \\
\hline Yanlış cevap & 3 & 10 & - & 0 \\
\hline Yanlış Cevap Tam Doğru Açıklama & - & 0 & - & 0 \\
Yanlış Cevap Kısmen Doğru Açıklama & - & 0.7 & - & 0 \\
Yanlış Cevap Yanlış Açıklama & 2 & 3.3 & - & 0 \\
Yanlış Cevap Açılama Yok & 1 & 0 & 1 & 0 \\
\hline Cevap Yok & - & & & 3.3 \\
\hline
\end{tabular}

Ön testte yanlış yapılan cevaplar son testte doğrulara çevrilmiştir. $\mathrm{Bu}$ soruda öğrencilerin çoğunluğu doğru cevap vermiş ancak açıklamalarındaki ifadeleri doğru değildir. Yapılan öğrenim sonrasında öğrencilerdeki doğru cevap doğru açıklama sayısında artış gözlemlenmiştir.

Örnek olarak bazı açıklamalar aşağıda verilmiştir.
ÖG: Lamba sayısını ne kadar arttırırsak parlaklık değişmez. (Ön Test)

ÖG: Çünkü her yerde aynı yanar. (Son Test) 
6. Aşağıdaki devrelerde anahtar kapatıldığında K, $L$ ve $M$ ampullerinin parlaklıkları ile ilgili aşağıdaki ifadelerden hangisi yanlıştır?

A. En parlak 1şık veren ampul L ampulüdür.

B. En sönük 1şık veren ampul $\mathrm{M}$ ampulüdür.

C. $\mathrm{K}$ ampulü $\mathrm{L}$ ampulünden daha parlak ${ }_{1} 1$ $1 \mathrm{k}$ verir.

D. $\mathrm{K}$ ampulü $\mathrm{M}$ ampulünden daha parlak 1 ş1 verir.

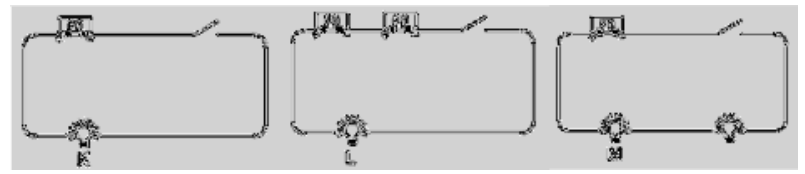

\section{Verdiğiniz cevabın nedeni:}

Altıncı sorunun analizi ve bulguları Tablo 6'da verilmiştir.

Tablo 6: Altıncı soru analizinden elde edilen veriler

\begin{tabular}{lcccc}
\hline & \multicolumn{2}{c}{ Ön Test } & \multicolumn{3}{c}{ Son Test } \\
\hline & $\mathrm{f}$ & $\%$ & $\mathrm{f}$ & $\%$ \\
\cline { 2 - 5 } Doğru Cevap & 18 & 60 & 25 & 83.3 \\
\hline Doğru Cevap Tam Doğru Açıklama & 1 & 3.3 & 9 & 30 \\
Doğru Cevap Kısmen Doğru Açıklama & 10 & 33.3 & 13 & 43.3 \\
Doğru Cevap Yanlış Açılama & 2 & 6.7 & 1 & 3.3 \\
Doğru Cevap Açıklama Yok & 5 & 16.7 & 2 & 6.7 \\
\hline Yanlıș cevap & 9 & 30 & 3 & 10 \\
\hline Yanlış Cevap Tam Doğru Açıklama & - & 0 & - & 0 \\
Yanlıș Cevap Kısmen Doğru Açıklama & - & 0 & - & 0 \\
Yanlış Cevap Yanlış Açıklama & 4 & 13.3 & 3 & 10 \\
Yanlıș Cevap Açıklama Yok & 5 & 16.7 & - & 0 \\
\hline Cevap Yok & 3 & 10 & 2 & 6.7 \\
\hline
\end{tabular}

Ön testte açıklama yapamayan öğrenci sayısı son testte azaltılmıştır. Öğrencilerin birçoğu bu soruda ön testte karşılaştırma yapmakta biraz zorlanmıştır ancak son testte doğru karşılaştırmayı yapmışlardır. Örnek olarak bazı açıklamalar aşağıda verilmiştir.

ÖB: (Ön test açıklaması yok)

ÖB: Çünkü C şıkkında yanlışlık var yanlışlık nedeni birinde 2 pil birinde 1 pil var. 2 pil daha güçlü olduğu için $\mathrm{L}$ ampulü $\mathrm{K}$ ampulünden daha parlaktır. (Son Test)

7. Aşağıda verilen devreler özdeş ampul ve pillerden oluştuğuna göre, hangi ampul en parlak yanar?

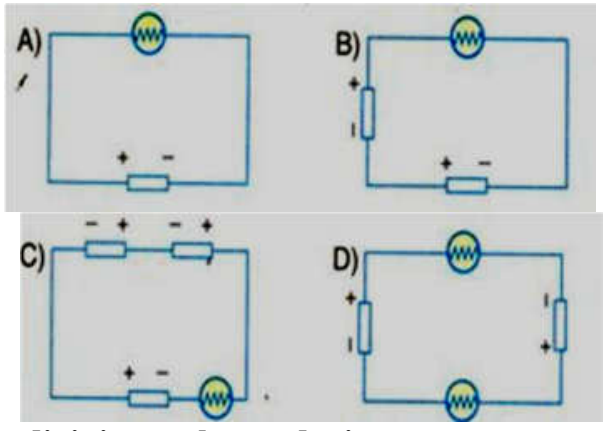

Verdiğiniz cevabın nedeni:

Yedinci sorunun analizi ve bulguları Tablo 7'de verilmiștir.

Tablo 7: Yedinci soru analizinden elde edilen veriler

\begin{tabular}{|c|c|c|c|c|}
\hline \multirow[b]{3}{*}{ Doğru Cevap } & \multicolumn{2}{|c|}{ Ön Test } & \multicolumn{2}{|c|}{ Son Test } \\
\hline & $\mathrm{f}$ & $\%$ & $\mathrm{f}$ & $\%$ \\
\hline & 18 & 60 & 29 & 96.7 \\
\hline Doğru Cevap Tam Doğru Açıklama & 2 & 6.7 & 6 & 20 \\
\hline Doğru Cevap Kısmen Doğru Açıklama & 12 & 40 & 23 & 76.7 \\
\hline Doğru Cevap Yanlış Açıklama & - & 0 & - & 0 \\
\hline Doğru Cevap Açıklama Yok & 4 & 13.3 & - & 0 \\
\hline Yanlış cevap & 12 & 40 & 1 & 3.3 \\
\hline Yanlış Cevap Tam Doğru Açıklama & - & 0 & - & 0 \\
\hline Yanlış Cevap Kısmen Doğru Açıklama & - & 0 & - & 0 \\
\hline Yanlış Cevap Yanlış Açıklama & 4 & 13.3 & 1 & 3.3 \\
\hline Yanlış Cevap Açıklama Yok & 8 & 26.7 & - & 0 \\
\hline Cevap Yok & - & 0 & - & 0 \\
\hline
\end{tabular}

Ön testte yapılan yanlışlıklar çok büyük bir fark oraniyla (\%36.7) son testte olumlu sonuca ulaşılmıştır. Öğrenciler bu soruda ön testte karşılaştırma yaparken zorlanmışlardır. Ayrıca lambanın fazla olması parlaklığın fazla olması düşüncesiyle yanlış cevap vermişlerdir. Son testte öğrencilerin büyük çoğunluğu kısmen doğru açıklama ile doğru sonuca ulaşmışlardır.

Örnek olarak bazı açıklamalar aşağıda verilmiştir. 
ÖE: A’nın enerji kaynağında 1şık kaynağına aittir. (Ön Test)

ÖE: Çünkü C de diğerlerine göre enerji fazladır. (Son Test)

8.

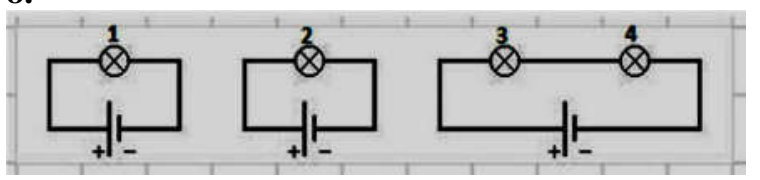

Yukarıdaki elektrik devrelerindeki ampullerin parlaklıkları arasında nasıl bir ilişki vardır?
A. $1>2>3>4$
B. $1=2>3=4$
C. $3>4>1=2$
D. $2>3>4>1$

Verdiğiniz cevabın nedeni:

Sekizinci sorunun analizi Tablo 8'de verilmiştir.

Tablo 8: Sekizinci soru analizinden elde edilen veriler

\begin{tabular}{|c|c|c|c|c|}
\hline & \multicolumn{2}{|c|}{ Ön Test } & \multicolumn{2}{|c|}{ Son Test } \\
\hline & $\mathrm{f}$ & $\%$ & $\mathrm{f}$ & $\%$ \\
\hline Doğru Cevap & 14 & 46.7 & 18 & 60 \\
\hline Doğru Cevap Tam Doğru Açıklama & - & 0 & - & 0 \\
\hline Doğru Cevap Kısmen Doğru Açıklama & 5 & 16.7 & 14 & 46.7 \\
\hline Doğru Cevap Yanlış Açıklama & - & 0 & 3 & 10 \\
\hline Doğru Cevap Açıklama Yok & 9 & 30 & 1 & 3.3 \\
\hline Yanlış Cevap & 15 & 50 & 12 & 40 \\
\hline Yanlış Cevap Tam Doğru Açıklama & - & 0 & - & 0 \\
\hline Yanlış Cevap Kısmen Doğru Açıklama & - & 0 & - & 0 \\
\hline Yanlış Cevap Yanlış Açıklama & 6 & 20 & 10 & 33.3 \\
\hline Yanlış Cevap Açıklama Yok & 9 & 30 & 2 & 6.7 \\
\hline Cevap Yok & 1 & 3.3 & - & 0 \\
\hline
\end{tabular}

$\mathrm{Bu}$ soruda öğrenciler zorlanmış olup hem doğru cevap kısmın sayısında artış varken hem de yanlış cevap yanlış açıklama kısmında artış gözlemlenmiştir. Öğrencilerde kavram yanılgısı oluşmuş açıklama yapılmamış kısmındaki azalış yanlış cevap yanlış açıklama kısmına kaymıştır. Örnek olarak bazı açıklamalar aşağıda verilmiştir.

ÖT: Ön testte açıklama yok.

ÖT: Çünkü bir tane pil olup bir tane ampul olur. (Son Test)

\section{Sonuç ve tartışma}

$\mathrm{Bu}$ araştırma ile 5E modeline uygun sorgulamaya dayalı öğrenme planı hazırlanmıştır. Beşinci sınıf ögrencilerine lamba parlaklığı konusu öğretimi yapılmıştır. Uygulanmış olan ön test ve son test sonuçları incelenmiştir. İnceleme, öğrencilerdeki kavramları ön teste göre ve son teste göre bilimsellik ve doğruluk acısından yapılmıştır. Araştırmanın bulgularına göre ön test ve son test arasındaki değişime bakılmıştır. Değişim anlamlı çıkmış olup öğrencilerde sorgulamaya dayalı öğrenme yönteminin etkisinin var olduğu görülmüştür.

Soruların açıklamalarına baktığımızda ön testte öğrencilerde yaşanmışlıklardan dolayı kavram yanılgısı ortaya çıkmıştır. Lamba sayısındaki artışın lamba parlaklığının artışına sebep olacağını düşünmüşslerdir. Ancak öğrenim sonrasında bu düşüncelerini deneysel plan sayesinde kendileri yaparak ve yaşayarak öğrenmişlerdir. Lamba parlaklığını etkileyen bir diğer unsur ise pil sayısı ve ögrrenciler pil sayısı konusunda ön test ve son teste çoğunluk olarak doğru cevap vermişlerdir.

Ön testte verilmiş olan yanlış cevaplar son testte düzeltilmiş bilimsel açıklamalarla desteklenmiştir. Öğrencilerin ön testteki yanlış sayısı son teste bakıldığında azalmıştır. Öğrencilerin sorguladıkları ve doğru olarak bildiği yanlışları yaparak öğrenmelerinin daha basit olduğu görülmüştür. [7]

Öğrencilerin geleneksel anlatım ile başarısının yükselebileceği konusu hakkında yorum yaparsak evet başarısında yükselme olacaktır ancak sorgulamaya dayalı öğrenme ile gerçekleşen eğitimdeki başarı etkisi ile geleneksel anlatımdaki başarı etkisi eşit çıkmayacaktır. Yapılan birçok araştırmada bu sonuç elde edilmiştir. [8-10]

\section{4. Öneriler}

$\mathrm{Bu}$ çalışmadan elde edilen sonuçlar doğrultusunda yapılan öneriler aşağıda yer almaktadır.

$\mathrm{Bu}$ çalışmada tek grup örneklem ile ön test ve son test yapılmıştır. Diğer çalışmalarda deney ve kontrol grupları ile elektrik kavramlarının ögretiminde öğretim öncesi ve sonrası farkların araştırıldığı çalışmalar yürütülebilir. Yapılmış olan çalışma sonucu öğrenciler ile vermiş oldukları cevaplar konusunda görüşmelerle desteklenebilir.

Sorgulamaya dayalı öğrenme yaklaşımı ile farklı konularda ve farklı yaş gruplarında öğretimin gerçekleştirileceği çalışmalar yapılabilir. 
Sorgulamaya dayalı öğretim, 5E modeli TGA tekniği ile desteklenerek plan hazırlanıp uygulama yapılabilir.

\section{Kaynaklar}

[1] Billings, L.R., Assessment of the learning cycle and inquiry based learning in high school physics education. Unpublished M. A Thesis, University of Michigan (2001).

[2] Roth ,W.M. ve Roychoudhury, A., Physics students' epistemologies and views of knowing and learning. Journal of Research on Science Teaching. 31, 1, 5-30, (1994).

[3] Tobin, K., Student task involvement and achievement in process-oriented science activities. Science Education. 70, 1, 61-72, (1986).

[4] Perry, V.R. ve Richardson, C.P., The new mexico tech master of science teaching program: an exemplary model of inquirybased learning. 31 st ASEE/IEEE Frontiers in Education Conference. Reno. (2001).

[5] Wilder, M. and Shuttleworth, P., Cell inquiry: A 5E learning cycle lesson. Science Activities, 41, 4, 37-43, (2005).

[6] Erdoğan, M.N., İlköğretim 7. öğrencilerinin atomun yapısı konusundaki başarılarına, kavramsal değişimlerine,
Sorgulamaya dayalı öğretimin bilimsel süreç becerilerini geliştirmek için uygun bir öğretim şekli olup olmadığı araştırılabilir.

bilimsel süreç becerilerine ve fene karş1 tutumlarına sorgulayıcı araştırma (inquiry) yönteminin etkisi, Yayınlanmamış Yüksek Lisans Tezi. Gazi Üniversitesi, Eğitim Bilimleri Enstitüsü, Ankara (2005).

[7] Yaşar, Ş. ve Duban, N., Sorgulamaya dayalı öğrenme yaklaşımına yönelik öğrenci görüşleri, Elementary Education Online, 8, 2, 457-475, (2009).

[8] Tatar, N. ve Kuru, M., Fen eğitiminde araştırmaya dayalı öğrenme yaklaşımının akademik başarıya etkisi, Hacettepe Üniversitesi Eğitim Fakülttesi Dergisi, 31, 147-158, (2006).

[9] Gençtürk, H.A. ve Türkmen, L., İlköğretim 4. sınıf fen bilgisi dersinde sorgulama yöntemi ve etkinliği üzerine bir çalışma, Gazi Eğitim Fakültesi Dergisi, 27 (1), 277-292, (2007).

[10] Sarı, U. ve Güven, G.B., Etkileşimli tahta destekli sorgulamaya dayalı fizik öğretiminin başarı ve motivasyona etkisi ve öğretmen adaylarının öğretime yönelik görüşleri, Necatibey Eğitim Fakültesi Elektronik Fen ve Matematik Eğitimi Dergisi, 7 (2), 110143, (2013). 